\title{
Anđel Starčević, Mate Kapović i Daliborka Sarić (2019) Jeziku je svejedno, Sandorf, Zagreb.
}

Pred nama je knjiga troje lingvista zaposlenih na Filozofskom fakultetu u Zagrebu, posvećena borbi protiv jezičnoga preskriptivizma. Podijeljena je u dva velika dijela: prvi, pod naslovom »Preskriptivizam i ideologija standardnog jezika« (str. 17-216) postavlja teorijske okvire, donosi definicije pojmova, objašnjava što je po mišljenju autora standardni jezik, što je preskriptivizam i zašto je on društveno štetan, zašto su jezičnopolitička pitanja po autorima uvijek ideološki obojena, te u čemu se sastoji »ideologija standardnog jezika« i kako nam kritička analiza diskurza može pomoći da je prepoznamo. Zatim polemiziraju s pogledima na standardni jezik onih lingvista koje autori smatraju "preskriptivistima (a to su, barem u hrvatskoj lingvistici, svi naši vodeći standardolozi) te kritiziraju teorije standardnog jezika proizašle iz tradicionalnog francuskog normativizma (u kojem je Académie Française stoljećima igrala ulogu službenoga regulatora), ali i iz praške standardološke škole B. Havráneka i V. Mathesiusa. U prvom se dijelu i odgovara na kritike koje bi, po autorima, njihovom odbacivanju preskriptivizma mogle biti upućene. U drugom dijelu knjige, pod naslovom "Anatomija hrvatskog preskriptivizma« (str. 217-365) autori oprimjeruju svoje teze o ideologiji standardnoga jezika konkretnim slučajevima lektorskih intervencija i jezičnih savjeta koje su pronašli u medijima i tiskanim jezičnim savjetnicima. Preskriptivističku ideologiju oni tako dekonstruiraju na »ideologiju tradicije i statičnosti« (po kojoj je u jeziku navodno dobro i prihvatljivo samo ono što je naslijeđeno od starine), »ideologiju standardnog jezika i formalnog stila« (po kojoj je standardni jezik navodno superioran dijalektima i svim nestandardnim idiomima), »ideologiju doslovnog značenja " (koja poriče metaforizaciju u jeziku, iako je ona sveprisutna, te zabranjuje nedoslovne izričaje u standardu), »ideologiju logike i simetričnosti« (po kojoj iskazi na standardnom jeziku moraju biti inherentno »logični«, što god to u pojedinim slučajevima konkretno značilo), ideologiju »antiredundancije« (po kojoj u standardnom jeziku valja paziti da se ne izražavamo redundantno, iako je redundancija uvijek prisutna u komunikaciji), »ideologiju purizma« (po kojoj valja izbjegavati tuđice i posuđenice, iako nijedan jezik na svijetu nije bez posuđenica), te »ideologiju izvornog jezika« (po kojoj koristeći riječi stranoga podrijetla moramo poštovati neka pravila jezika-izvornika, npr. rod imenica u latinskom). Na koncu, slijedi kratko poglavlje "Prije zaključka« (str. 366-7) napisano na nestandardnom idiomu kojim se autori, pretpostavljamo, služe u svakodnevnom životu i u kojem se još jednom ističe teza o neznanstvenosti preskriptivizma. Na koncu su knjige »Zaključak« (368-376), popis izvora i opsežna bibliografija (379-393) te bilješka o autorima.

Počnimo s onim što se o ovoj knjizi može pozitivno reći. Autori na primjerima pokazuju do kakvih bezumnosti može doći ako se sve u standardnom jeziku želi propisati, odnosno kada se donose arbitrarni propisi o onome što u jeziku ne bi tre- 
balo biti propisano. Doista se možemo zapitati na temelju čega jezični savjetnici tvrde da nije standardno govoriti upaliti televizor jer se time implicira da je televizor izložen vatri (kao da u jeziku ne postoji metaforizacija), ili da pošto može biti samo vremenski, a ne i uzročni veznik, kada su i najranije potvrde uporabe toga veznika u hrvatskoj književnosti uzročne, a ne vremenske - autori su se potrudili i provjerili su (str. 104). Takvi primjeri čitatelju mogu biti zabavni, a u knjizi ih je skupljeno mnoštvo. Naravno, postavlja se pitanje smislenosti prikupljanja svega budalastoga što je o standardnom jeziku napisano ili u medijima izrečeno, jer čitatelj ostaje uskraćen za one jezične savjete koji su njihovim korisnicima (svima koji konzumiraju jezične savjetnike ili daju svoje tekstove lektorirati) korisni - recimo tako što su im pomogli da se izraze jasnije i na način da budu razumljiviji većem krugu čitatelja ili slušatelja. Zanimljiva je u ovoj knjizi i klasifikacija strategija kojom jezični savjetnici izmišljaju proizvoljne jezične savjete (autori ih zovu »ideologijama«, str. 217-365), kao i originalna tipologija "grešaka« koje preskriptivisti pronalaze u jezičnim iskazima koji im se ne sviđaju (str. 43-44). Također, autorima se ne može poreći da pišu jasno i pregledno, te da dobro poznaju standardološku literaturu koju kritiziraju. To im omogućuje da u njoj pronalaze uglavnom one citate koji potvrđuju njihovu tezu da je jezična preskripcija zasnovana na opresivnoj ideologiji, nažalost ne vodeći računa o povijesnom kontekstu u kojem su ti citati nastali. Pa ipak, ako treba sažeti ono najbolje što se može reći o ovoj knjizi: ona jasno pokazuje kako jezične savjete ne treba pisati. Autori su sigurno u pravu kada ističu da nema ništa loše u postojanju varijacija u normi, čak i kada nije jasno kakva je funkcionalna ili stilistička razlika između supostojećih varijanata. Hiperreguliran jezik je poput hiperregulirane države: disfunkcionalan i neučinkovit.

$S$ druge strane, mnogo toga u ovoj knjizi objektivnoga čitatelja mora ostaviti u nedoumici. Argument kojim se služe autori da dokažu svoje teze ide otprilike ovako: jezik je konvencija, pa je i standardni jezik (odnosno varijetet, kako pišu autori) konvencionalan, i nije ni po čemu »bolji« od nestandardnih varijeteta. Oni koji ga idealiziraju pod utjecajem su »ideologije standardnoga jezika« koja je po svojoj naravi represivna, jer negativno gleda na druge i drukčije, na sve koji ne prihvaćaju »naš« standardni jezik. U službi su te ideologije i jezični savjetnici i lektori, koji imaju i financijski interes da javnost tu ideologiju prihvaća, jer zbog nje konzumira i jezične savjete i lektorske intervencije koje se predstavljaju kao znanstveno utemeljene, iako to nisu. Obični ljudi zbog toga pate, jer im jezični savjetnici neprekidno nameću osjećaj manje vrijednosti i jezične nekompetentnosti. Zato trebamo jezične aktiviste, u koje se ubrajaju i autori ove knjige, koji će raskrinkati ideologiju standardnoga jezika i pokazati ljudima da su oni gospodari vlastitoga jezika, koji treba služiti njima, a ne obratno.

Autori imaju posve pravo kad tvrde da »kako valja govoriti (ili pisati)?« nije znanstveno pitanje o jeziku, budući da uključuje vrijednosni stav, a znanost nikada ne odgovara na pitanje kako nešto treba biti, već samo kako nešto jest: znanost je po definiciji nastojanje utvrđivanja novih činjenica i pravilnosti koje ih povezuju, 
odnosno prirodnih zakona. Jezični savjetnici, koji govore kakav bi jezik trebao biti, stoga nisu znanstveni, no to ne znači da ljudi koji se bave jezičnim savjetništvom ne trebaju ništa znati: naprotiv, moraju više od prosječne osobe znati koliko je u društvu rasprostranjena uporaba pojedinih riječi i konstrukcija, koja su najčešća i otprije proširena značenja riječi, a koja su rezultat inovacijā. Primjeri koje su autori prikupili pokazuju da jezični savjetnici često ne čine tako - lakše je izmisliti proizvoljno pravilo i opravdavati ga time da je tako »ljepše, logičnije, jasnije (ili što god slično), nego prekopavati rječnike i povijesne izvore da bi se dokazalo što je proširenije i čvršće utemeljeno u tradiciji.

Najveći problem s ovom knjigom nastaje zbog toga što autori inzistiraju na ideološkoj determiniranosti stavova o jezičnoj politici. Oni eksplicitno tvrde (bez ikakvog dokaza ili empirijske potkrijepe) da »neutralan pogled na jezična pitanja ne postoji (str. 68; navođenje autoriteta kao Irvine \& Gal 2000, Milroy \& Milroy $2012 \mathrm{i}$ Blommaert 1999 trebalo bi poslužiti umjesto empirijske potkrepe ove teze). Nažalost, takvo gledanje ima dalekosežne posljedice: ako su oni kojima je stalo do kontinuiteta i usporavanja promjena standardnoga jezika po definiciji reakcionari koji žele zacementirati odnose moći u društvu, dok su protivnici svakog preskriptivizma po svojoj naravi aktivisti koji žele osloboditi društvo od konzervativne stege, tada je dijalog između tih dviju skupina praktički nemoguć. Takav stav vodi do toga da se svaki napor oko održavanja norme mora shvatiti kao "preskriptivističko ugnjetavanje govornikâ nametanjem proizvoljnih pravila« (str. 69), što za posljedicu ima »odrugotvorenje« svih koji ne govore standardno i, u konačnici, perpetuiranje nametnutih društvenih struktura i hijerarhija moći. Onima koji tako misle nikada ne će biti prihvatljiva zamisao da su lektori i/ili jezični savjetnici samo ljudi koji pošteno rade svoj posao i pokušavaju korisnicima njihovih usluga pomoći da se izraze jasnije, na način koji će biti lakše razumljiv većini stanovnika Hrvatske, a ujedno i više u skladu s normom čija je naslijeđena tradicionalnost po sebi društvena vrijednost. Ono što autori nazivaju »ideologijom standardnog jezika«, koju prikazuju kao neku vrst dogmatskoga sustava s rigidnim tezama, zapravo je skup vrijednosnih stavova koji nisu logički povezani, tako da netko može prihvaćati jedne, a osporavati druge. Primjerice, logički je konzistentno vjerovati da je standardni jezik određen "normom ", ali da u okviru norme može supostojati više stilski i funkcionalno izdiferenciranih dubleta, tj. da standardni jezik može sadržavati istoznačnice koje su podjednako dio norme; možete istovremeno smatrati da je standardni jezik određen tradicijom i da se ne treba prebrzo mijenjati, a ipak prihvaćati da su promjene nužne i da se mogu ostvarivati i posuđivanjem iz drugih jezika, tj. možete istovremeno biti tradicionalist i ne biti purist. Možete istovremeno naglašavati važnost standardnoga jezika za nacionalni identitet, povijest i kulturu, a poricati da je on inherentno »bolji od supstandardnih varijeteta i dijalekata koji nacionalnoj kulturi doprinose na drugi način. Slično je is »pluralističko-progresivnom « ideologijom koju zastupaju autori: i nju je bolje shvatiti kao skalu vrijednosnih stavova koji ne moraju biti prihvaćeni »u paketu«: netko, poput autora ovih redaka, može 
vjerovati da je standardni jezik važan simboličko-identitetski element mnogih nacija (uključujući i hrvatsku), no istovremeno smatrati očuvanje jezične i dijalekatske raznolikosti civilizacijskim dostignućem, kao i vjerovati da država ne bi trebala zadirati u slobodu jezičnoga izražavanja zakonski propisujući javnu uporabu standardnoga jezika (za njegovanje standarda potreban je efikasan obrazovni sustav i kulturne institucije, a ne zakonska regulativa). Promatranje standardnoga jezika kroz prizmu suprotstavljenih "ideologija « zamagljuje sliku i otežava suočavanje s konkretnim problemima jezične politike u nekom društvu.

Drugi je problem što autori ne nastoje svoje teze empirijski dokazati. Kao što nemamo empirijskih podataka o tome koliko lektora i jezičnih savjetnika loše obavlja svoj posao (prikupljeni primjeri u knjizi ne predstavljaju statistiku, a lako je pronaći primjere loše prakse za bilo koju djelatnost), tako ne znamo ni u kojoj je mjeri istina da ta nesavjesna praksa ima loše posljedice, odnosno da kod govornika dovodi do "shizoglosije - nigdje nam se ne nude nikakve statistike zasnovane na objektivnom uzorkovanju. Zbog toga ne znamo čine li jezični savjetnici doista golemu društvenu štetu poput protivnika cijepljenja, ili su više poput loših referenata za odnose s javnošću kakve zapošljavaju mnoge institucije (ako i rade neku štetu, društvo u cjelini od toga previše ne trpi). Prije će biti da su autori nekritički na hrvatske prilike preslikali sociolingvističku situaciju iz anglosaksonskog svijeta, u kojem dijelu stanovništva dugo nije bilo omogućeno obrazovanje na standardnom jeziku (crncima u SAD, pripadnicima niže klase i imigrantima u Velikoj Britaniji), pa je opasnost da će netko zbog idioma kojim govori biti diskriminiran uistinu postojala, a donekle još uvijek postoji. U Hrvatskoj, koja ima opće obrazovanje na jedinstvenom standarnom jeziku već više od stotinu godina, i gdje su sociolekatske razlike između privilegiranih i manje privilegiranih društvenih skupina mnogo manje izražene, takve opasnosti nema, a onda ni potrebe za aktivistima koji bi ispravljali navodne društvene nepravde vezane uz jezik.

Karakteristično je i da je "aktivizam ", prema autorima, samo lijevi (marksističko-egalitaristički) aktivizam, a nastojanja onih koji se brinu o standardnom jeziku samo su »ugnjetavanje masa (desni aktivizam, čini se, u tom svjetonazoru ne može postojati). Demokratsko pravo onih koji svjesno žele govoriti ili se pismeno izražavati tako da pokažu svoju obrazovanost, poštovanje hrvatske tradicije, ili čak pripadnost nekoj društvenoj skupini (zašto ne?) autori ne prihvaćaju.

Dio nedosljednosti u ovoj knjizi možda je posljedica i neslaganja među njezinim autorima, pa čitatelj može samo nagađati imaju li oni uistinu jedinstven stav o problemima o kojima pišu. Primjerice, ne želeći izrazom »standardni jezik« implicirati da drugi varijeteti u nekom društvu (dijalekti, sociolekti) nisu ravnopravni »jezici«, usporedno koriste termine »standardni varijetet « $\mathrm{i}$ »standardni dijalekt«, pri čemu je ovaj potonji termin, preuzet iz anglosaksonske tradicije, u suprotnosti s hrvatskom lingvističkom terminologijom i nepotrebno unosi zbrku. Na sličan način, autori izričito tvrde da nisu protiv standarda, već samo protiv preskriptivizma (npr. na str. 24-25). Međutim, u »Zaključku«(str. 369) zapravo osporavaju potrebu 
za standardnim jezikom, ističući da su mnoga društva tisućama godina postojala i bez njega (to je točno, kao i bez penicilina), te ponavljaju vrlo proširenu dogmu da standardni jezici nastaju tek s modernim nacionalnim državama (kao da latinski nije bio standardiziran jezik još od Augustova vremena; autori spominju slučaj latinskoga na str. 31, ističući kako on nije bio rezultatom "modernog tipa normiranja «, i time upadaju u cirkularnost, jer ako se standardom smatra samo idiom nastao putem »modernog tipa normiranja«, onda standardnih jezika po definiciji nema prije modernog razdoblja). Isto tako, kada govore o tome kakav bi standard trebao biti, kažu da bi on trebao biti »fleksibilan, ne bi trebao previše odudarati od živoga jezika i glavna nit vodilja u normiranju morala bi biti jezična upotreba a ne tradicija ili osobne preferencije standardologā« (str. 209). Dok će se s većinom izrečenoga zacijelo složiti mnogi standardolozi (rekao bih i većina njih), nije jasno zbog čega je tradicija stavljena na istu razinu $s$ »osobnim preferencijama standardologa«? Nije li tradicija ugrađena u standardni jezik te ju, ako to želi većina njegovih govornika, također valja poštovati pri normiranju? Jasno, tradicija nije univerzalna vrijednost, no ako većina govornika drži do nje i smatra je važnim činiocem nacionalnoga identiteta, kako je možemo zanemariti? Autori će na to odgovoriti da je to posljedica nacionalističke ideologije, i onda se opet vraćamo na početak, jer ako je sve u jezičnoj politici posljedica fiksnih ideologija koje zarobljavaju um svojih sljedbenika, teško da se u društvu o bilo čemu možemo dogovoriti.

Meni se pak čini da stvari ovako stoje: standardni je jezik konvencija, i kao sve druge društvene konvencije može se promijeniti. I normalno je da se s vremenom mijenja. U Hrvatskoj bismo, da većina njezinih građana to želi, mogli odabrati i neki drugi jezik umjesto hrvatskoga za službeni, i kada bismo odabrali engleski, dokazivo bismo dugoročno od toga imali ekonomske koristi. Pa ipak to ne činimo i ne ćemo učiniti jer civilizirana društva poštuju na tradiciji utemeljene konvencije i ne odlučuju o njima uvijek iznova: primjerice, hoćemo li konvenciju po kojoj jedemo vilicom i nožem promijeniti u konvenciju po kojoj jedemo štapićima ili rukama? A kada se radi o tradiciji koja zadire u simboličko-identitetska pitanja, kao što je jezik, još je manje vjerojatno da ćemo je mijenjati. To je slično kao is državnim uređenjem: neke su vrlo demokratske države poput Danske ili Švedske po tradiciji monarhije, i njihovi bi građani mogli (recimo na referendumu) odlučiti da žele postati republika. Pa ipak to ne čine, čak ni kada bi u redovnim izbornim ciklusima mogli, zato jer drže do tradicije koja u velikoj mjeri određuje identitet njihove zemlje. Iz istoga razloga većina govornika hrvatskoga ne gleda na vlastiti jezik samo kao na konvenciju, koja se u svakom trenutku može proizvoljno mijenjati i služi samo učinkovitoj komunikaciji, već i kao na dio nacionalne tradicije koju zbog simboličke važnosti ne treba mijenjati.

$\mathrm{Da}$, norma koja određuje što je standardni jezik je u najvećoj mjeri konvencionalna, a ne rezultat svjesnoga odabira po nekim racionalnim kriterijima. Da, kao i sve konvencije, i sve u vezi sa standardnim jezikom može biti predmetom demokratskoga odlučivanja, no bilo bi nepraktično da se o tome koliko standard valja 
mijenjati odlučuje svakih nekoliko godina. U nedostatku jakih razloga da se misli suprotno (tj. ako ne povjerujemo da smo svi zavedeni »ideologijom standardnog jezika«) možemo pretpostaviti da većina stanovnika ove zemlje želi standardni jezik koji se mijenja samo onoliko koliko je potrebno da u nekom društvu omogući ne samo djelotvornu komunikaciju u sinkroniji (među svim pripadnicima komunikacijske zajednice), već i u dijakroniji, odnosno da omogući razumijevanje ključnih tekstova nacionalne kulturne baštine što većem broju pokoljenjā. Autori odbacuju ovaj posljednji argument (str. 98), tvrdeći da inzistiranje na konzervativnoj normi ne će pomoći današnjoj djeci da bolje razumiju Držića. To je, naravno, točno, ali to ionako nitko ne tvrdi; međutim, ustrajemo li danas na konzervativnoj naravi standarda pomoći ćemo budućim generacijama da lakše razumiju Kamova, Krležu i Cesarića. Tvrditi da je samo važno »da se razumijemo«, sada i ovdje, kao da nacionalna prošlost i budućnost ne postoje, znači poreći simbolično-identitetsku funkciju standardnoga jezika i nije daleko od tvrdnje da on uopće nije potreban.

Na koncu, možemo se zapitati - hoće li ova knjiga išta bitno promijeniti u društvu i njegovu stavu prema standardnom jeziku? Mišljenje je ovoga recenzenta da ne će, već će zbog svojeg dogmatskog inzistiranja na ideološkoj naravi debate o problemima standardnoga jezika samo povećati konflikte, kojih u hrvatskom javnom prostoru ionako ne nedostaje. Ako one s kojima se ne slažete u nekim vrijednosnim stavovima etiketirate kao u najboljem slučaju mutikaše koji svoje vlastite materijalne interese prodaju pod znanost, a u najgorem kao zatucane reakcionare koji tlače i vrijeđaju druge i drukčije (npr. na str. 212), teško možete očekivati da ćete promijeniti njihove stavove, ili navesti šutliivu većinu da prihvati vaše.

Ranko Matasović 